ARTICLE

DOI: $10.1057 /$ s41599-018-0100-1

\title{
Beyond ideological platitudes: socialism and psychiatry in Eastern Europe
}

Mat Savelli ${ }^{1}$

\begin{abstract}
For both contemporaneous commentators and historians, psychiatry within what was Communist Europe has largely been discussed through the prism of politics and ideology. Recently, scholars have begun to debate the extent to which psychiatric practices within post-WWII Eastern Europe were beholden to the ideological aspirations of the political elite. This paper enters into these debates by suggesting the need for more nuance in how historians analyse the relationship between ideology and psychiatry in this context. Specifically, it argues that there is a need to differentiate between psychiatric practices that were socialist by design-where professional knowledge was theoretically guided by ideological considerations-and those that were socialist by default-where practices were shaped by the socialist context without being meaningfully inspired by ideology. In order to demonstrate these distinctions, this paper reflects upon psychiatric developments within Communist Yugoslavia (1945-1991). By drawing a clearer distinction between "socialist by design" and "socialism by default", it becomes easier to reconnect Eastern Europe to the broader historiography of twentieth century psychiatry, while simultaneously providing new insights into the experience of state-sponsored Communism.
\end{abstract}

\footnotetext{
${ }^{1}$ McMaster University, Hamilton, ON, Canada. Correspondence and requests for materials should be addressed to M.S. (email: savellm@mcmaster.ca)
} 


\section{Introduction}

uring the Cold War, articles about "socialist psychiatry" punctuated Western medical journals, usually in the form of dispatches from Western mental health care workers who had engaged in short exploratory trips to East European psychiatric facilities (e.g., Aronson and Field, 1964; Field and Aronson, 1965; Ziferstein, 1966; Moss, 1967; Hess, 1971; Allen, 1973; Salvendy, 1975). Although the tone of these reports oscillated from respect and admiration (especially for the Soviet commitment to community care) to dismissal and disdain, virtually all of these pieces were pervaded by a sense of the exotic, not merely reflecting upon alternative approaches to diagnostics and treatment, but rather bringing back images "from the other side." While the authors might touch on subjects such as hospital planning and the availability of Western medical literature, they also included detailed impressions of life beyond the Iron Curtain, with reference to how" typical citizens" dressed, spoke, and behaved. These sorts of details were both an indication of, and perhaps inadvertently a contributor to, the climate of Cold War rivalry. Although some reports (Kline, 1960, 1963) attempted to downplay the differences between East and West, many seemed to reflect a belief that East European citizens and practitioners were psychologically distinct from their Western counterparts, living within a system where the state's ideological devotion to socialism demanded conformity from its citizenry. From this perspective, then, the role of the East European psychiatrist was to ensure that patients could continue to fulfil their duties to the collective by adhering to the ideological dictates of the state. Within these reports, East European practitioners were typically framed as engaging in a socialist variant of psychiatry in their attempts to treat socialist citizens.

Suspicions about the overtly ideological character of East European psychiatry seemed to be confirmed by the 1970s, when rumours about the abuse of psychiatry for political purposes proliferated, especially relating to the Soviet Union. Westernbased human rights organisations and medical associations increasingly began reporting that political dissidents were being forcibly confined in psychiatric facilities for daring to challenge the Marxism-Leninism propagated by state authorities. Firsthand accounts from those suffering this abuse (Medvedev and Medvedev, 1971; Abuse of Psychiatry for Political Repression in the Soviet Union, 1973; Fainberg, 1975), in addition to the testimony of a small number of Soviet physicians themselves, revealed terrible misuses of medical power, wherein individual critics of the state were beaten by orderlies, given forced injections of psychopharmaceutical agents, and were made to endure long stretches of isolation within hospitals. Many accounts zeroed in on a specific diagnosis_-"sluggish schizophrenia"-as a catch-all category that could be used to justify the involuntary confinement of the state's political enemies. Condemnation of efforts to instrumentalize psychiatry for political purposes came from all corners, including academics (Fireside, 1979), physicians (Bloch and Reddaway, 1977), and human rights campaigners (Amnesty International, 1975). Throughout the decade, Western medical societies mounted campaigns to publicly shame East European authorities for these types of practices, ultimately prompting the Soviet withdrawal from the World Psychiatric Association. But while Western critics were unequivocal in their stance that the politicisation of psychiatry was both inappropriate and harmful, their explanations of how this process played out differed. Some advanced the idea that the practice was both deliberate and limited to a few proverbial bad apples, others instead focused on the possibility that a larger number of practitioners were unknowingly applying diagnostic criteria that was heavily shaped by ideology and the totalitarian nature of the USSR (Segal, 1977; Bloch, 1978; Reddaway, 1978). Regardless, the widespread concerns over psychiatric abuse helped to perpetuate the notion that mental health care in the East European context was inextricably bound to the ideological aspirations of the ruling elite.

This assumption-that psychiatry within the Communist world existed primarily to promote the goals of state socialist regimes-has attracted the attention of historians of medicine, many of whom are increasingly turning their gaze to Eastern Europe (and beyond). Politics and ideology are at the heart of emerging debates within this subfield, with participants attempting to work out exactly what might be distinctly socialist about medicine and mental health care within the Communist context. ${ }^{1}$ As of yet, no consensus has formed, and scholars seem split on exactly how central the ideological climate was to the unfolding of medical practices. On the one hand, some observers underscore the political nature of mental health care within this context; for example, they draw attention to the ways that certain types of therapeutic practices might be promoted or constrained because of their imagined relationship to Marxist ideals (Chehirian, 2017; Lambe, 2017) or suggest that diagnostic practices could be heavily informed by overarching desires to pathologize certain types of anti-socialist behaviour (Eghigian, 2004; Antic, 2016). By contrast, other observers have stressed that, although mental health care was of course not divorced from the political environment, we should be cautious about overemphasising the centrality of the state's preferred ideological discourse to its practice (Joravsky, 1989; Savelli, 2015). These scholars question the exoticized characterisations of East European psychiatry as isolated within a socialist bubble, arguing that the Iron Curtain did not prevent many practitioners from studying and contributing to professional discussions occurring in Western Europe and North America (Dufaud and Rzesnitzek, 2016; Marks and Savelli, 2015; Marks, 2015). Others note that some of the distinguishing features of East European psychiatry often predated Communist takeovers, so differences between West and East European mental health care practices cannot be simply attributed to the ideological context (Brown, 1994; Beer, 2007; Karge, 2017). Moreover, we should be careful not to treat psychiatric practices within any of these countries monolithically, as diverse and competing theories relating to mental illness proliferated even when paying lip service to the same ideological totem (Zajicek, 2009; Leuenberger, 2001; Gao, 2015).

This article enters into this broader debate, although it makes no attempt to provide any kind of definitive conclusion regarding the relationship between official ideology and psychiatric practices within Communist-era Eastern Europe. In truth, the contextual diversity and vicissitudes of chronology mean that any effort to provide a master narrative seem likely to fail. Instead, this paper aims to complicate the debate somewhat by encouraging scholars to consider a particular nuance in our conceptualisation of "socialist psychiatry." Specifically, it suggests that there is a need to distinguish between developments that were "socialist by design"-encompassing practices inspired by ideological considerations-versus those that were "socialist by default." In this second category, we might place events and knowledge that were shaped by the fact that they unfolded in a socialist context, but were not necessarily guided by that ideology. In other words, these developments could be better construed as consequences of the state's interpretation of socialism, rather than theoretically driven manifestations of it.

Distinguishing along these lines is important for several reasons. Firstly, it helps to address a much broader issue: the need to reconnect East European psychiatric history to that of the rest of the world. For too long, developments within the East European context have been either ignored or treated as something of a sideshow or quirk in the broader twentieth century history of 
science and medicine, rather than a constituent component of it. Although the reasons for this are complex, I suspect that it results from three primary factors: firstly, it echoes earlier Cold War era narratives about Communist science and medicine as backwards and out of step (reflected, for example, in the proliferation of scholarship around the biologist Trofim Lysenko, who led a campaign against Mendelian genetics). Secondly, it may be indicative of a popular tendency to understand science and medicine in Western Europe and North America as value-free, emerging in a climate void of ideology. ${ }^{2}$ Finally, it reflects a broader pattern that has taken root since the collapse of Soviet Union, in which virtually almost all developments within Communist Europe have been conceptualised as unmitigated failures, unworthy of serious consideration and lacking in any sort of consequent legacy. ${ }^{3}$ By thinking about the differences between "socialist by design" and "socialist by default," the connections between Eastern Europe and the rest of the world might become more apparent. For instance, from the "socialist by design" perspective, we might see parallels between Eastern Europe and those elsewhere that were inspired by Marxism, including the utopian variant of the international social psychiatry movement or Frankfurt School theories about human psychology. In terms of "socialist by default," meanwhile, East European psychiatric practices might be readily compared to those that unfolded in other one-party authoritarian regimes, such as those in Latin America. Ultimately, these types of comparisons would prove fruitful for broader discussions of medical history, scientific development, and politics, allowing us to see interconnections beyond specific ideological contexts.

Secondly, the conceptual distinction between "socialism by design" and "socialism by default" can act as a framework for debates on the relationship between scientific practices and ideology within other settings. A substitution of the word "socialism" for alternate political systems (e.g., "fascist", "neoliberal," "colonial") could be used by historians of science and medicine to yield richer analyses of how these ideological contexts structured epistemological and clinical developments. Despite its apparent simplicity, differentiating between that which was "by design" and that which occurred "by default" serves to sharpen analyses of how medical and scientific practices can simultaneously reinforce and reflect broader socio-political projects.

Finally, the division between "socialist by design" and "socialist by default" is significant for scholars who are trying to make sense of the grand Marxist-Leninist experiments of the twentieth century. As historians, we are still grappling with questions about the extent to which genuine ideological belief permeated everyday social practices. While it may be alluring to dismiss the possibility that citizens actively bought into the ideological fare served up by the state, we must assume that people's outlook and worldview were impacted by the political climate, at least to some extent. This issue is especially pertinent in relation to psychiatry, given the profession's status as an arbiter of "normal" (healthy, acceptable) and "abnormal" (ill, problematic) behaviour. If psychiatric knowledge was "socialist by design," it may have meaningfully shaped who was diagnosed and how they were treated. By contrast, if we see the profession as "socialist by default," then we might expect greater continuity between the actions of psychiatrists within the Communist world and those elsewhere.

While it would not be prudent to sketch too firm a binary between these concepts-on some level they were mutually reinforcing-the rest of the article will attempt to more fully explain this distinction between "design" and "default" by drawing upon psychiatric developments within Communist Yugoslavia (1945-1991).

\section{The Yugoslav context}

Historians of Communism have expended significant efforts in the attempt to delineate exactly what might constitute "the socialist experience" (Service, 2010; Brown, 2009; Crampton, 2005; Pipes, 2003; Priestland, 2016). In light of the immense sociocultural diversity that has characterised societies whose leaders dedicated themselves to the construction of a Marxist society, ranging from the USSR and China to Cuba, Angola, and Laos, among many others, this has been no easy task. At the heart of their work is a crucial debate-to what extent was Cold War era Communism a shared experience? While there might be a tendency to view the Soviet experience as the definitive account of what socialism looked like, with the subsequent assumption that Soviet hands controlled the levers of the global Communist movement, such an approach is oversimplified. It is certainly true that Soviet leaders eagerly meddled in the affairs of other Marxist-declared states, but it would be erroneous to assume that leaders in these states were merely doing Moscow's bidding. It would be equally fallacious to conclude that elites in these countries were somehow less ideologically committed than their Soviet counterparts.

Yugoslavia is an exemplar in this regard. Formed in 1918, the Kingdom of Serbs, Croats, and Slovenes (later Yugoslavia) disintegrated in the 1930s amidst political rivalries among the state's various ethnic groups. The Second World War was a particularly miserable time for Yugoslavs; in addition to Axis invasion and occupation, many towns were targeted by Allied bombing raids. Moreover, a brutal civil war erupted, with the main protagonists including royalist Serbian militias known as Cetniks, the Croatian fascist Ustase movement, and the Partisans, the antifascist resistance led Josip Broz Tito, the head of the Communist Party of Yugoslavia. Notably, the Partisans' multiethnic coalition of forces were later hailed as the embodiment of "brotherhood and unity" - an ideological touchstone of Yugoslav socialism. Despite their pride in having largely liberated the country independently, Yugoslavia quickly entered the Soviet sphere of influence. In time, however, the relationship between Yugoslavia and the USSR fractured over a series of economic and foreign policy disputes, as well as growing mutual distrust between the leaderships of both sides. In 1948 the Yugoslavs were officially expelled from the Cominform (the Soviet-controlled international organisation of Communist states), sparking a period of chaos within Yugoslavia as those loyal to Tito battled Stalinists for ascendancy.

Eventually victorious, the Titoists set about developing a socialist alternative to the Soviet model of governing society and the economy. In the early 1950s, the country's chief ideologists devised the notion of "self-managing socialism," centred on the notion that economic and political control could be decentralised so that workers had more direct say over how their workplaces and enterprises performed. Relative to the command economy of the Soviet Union, this translated into a more liberal approach to issues like markets, cultural practices, and travel (with people having a comparatively easy time passing through its borders). Over several decades, the country was dramatically reshaped through the implementation of self-management, with substantial reverberations at almost every level of Yugoslav life. Although the relationship with Moscow would be somewhat healed after Stalin's death, Yugoslavia positioned itself as a leader of the Non-Aligned Movement, developing relationships with both the West and East, as well as the Third World. In time, Yugoslavia emerged as an important player in the global context, ideologically committed to the establishment of Communism, albeit on its own terms. As the next sections will demonstrate, that ideological context was important for the development of Yugoslav psychiatry, although not always by design. 


\section{Socialist by design}

Scholars devoted to the study of mental health care in the state socialist context have convincingly demonstrated the ways in which officially sanctioned ideological stances informed psychiatric and psychological theories and practices. For example, shifts in the political environment within the Soviet Union created pressures to prioritise (or suppress) particular theories related to the causation, identification, and treatment of mental illness. In efforts to elucidate a particularly Soviet conception of psychiatry, the period from the 1930s to 1950s witnessed the promotion of theories that reflected the scientific-materialism associated with Marxism-Leninism. In practical terms, this development translated into attacks on those promoting both psychoanalysis (Miller, 1998; Etkind, 1997) and mental hygiene (Zajicek, 2014) in favour of somatic treatments that were understood as addressing the biological origins of psychiatric illness. The infamous Pavlov session of 1950 has been portrayed as a watershed moment in this regard (Windholz, 1997; Windholz, 1999), whereby the Pavlovian concept of mental illness as a problem resulting from higher cortical structures was firmly established, later being exported to (then) friendly nations, including China (Gao, 2015), Cuba (Lambe, 2017), Romania (Dobos, 2015) and others. At the same time, Marx's emphasis on the liberating potential of labour helped propel work therapy to a position of elevated importance within Soviet psychiatric hospitals (Sirotkina and Kokorina, 2015). Other scholars, meanwhile, have highlighted how diagnostic practices could be reimagined depending on how they related to the wider socialist project. For example, Lee (1999) points out that the diagnosis of depression carried connotations of self-absorption and laziness in the context of Mao's Cultural Revolution, while Leuenberger (2007) has demonstrated how psychiatrists in the German Democratic Republic (GDR) reconceptualised neuroses in light of their own interpretation of scientific-socialism.

In the above cases, the state's favoured conception of socialism played an active role in shaping the theory underpinning mental health care. Whether in terms of diagnostics or treatment, practitioners' sense of their patient-and human nature more broadly - reflected some form of the socialist ideal; ill individuals were to be diagnosed on account of their deviation from that ideal, or they might be treated as a way to restore it. Psychiatrists, in many cases quite purposefully, were consequently engaged in the process of elucidating a particularly socialist approach to the discipline, grounded in concepts like materialism, collectivism, and the centrality of work to people's sense of self. As Zajicek (2009) argues, it is fair to assume that although some practitioners referenced ideological platitudes to boost their career prospects, others probably quite genuinely believed that their ideas, grounded in Marxism-Leninism, were correct. In this regard, this type of psychiatric knowledge was socialist by design, understood by clinicians as contributing to the broader ideological struggle by helping to engineer new socialist citizens through the use of an emerging socialist science. Essentially, we might understand these types of practices as being subordinated to larger, overarching ideological goals.

To what extent did developments of this sort occur in Yugoslavia? In short, psychiatric practices that were socialist by design were comparatively rare in the Yugoslav context, but they were not totally absent, especially in the immediate postwar years. For example, Dezider Julius, a high ranking practitioner and former Partisan, made several speeches during the 1949 meeting of the country's neurologists and psychiatrists in which he stressed the need for self-criticism (a hallmark of Marxism-Leninism), praised the meeting for having been held "in the spirit of brotherhood and unity," and argued that the country's clinicians needed to deepen their knowledge of dialectical materialism (Zapisnik,
1951). Additionally, he read out a telegram to the Minister of Health that informed the Central Committee of the Communist Party that the country's psychiatrists would do everything within their powers to build up socialism and send a response to those who dared to speak against Yugoslavia. Moreover, Julius read out a letter to Tito himself, in which the neuropsychiatrists of Yugoslavia sent "greetings to you of their love and devotion for the struggle that you at the head of the Party and all of our people are waging" (Zapisnik, 1951, p 313) Although it is possible that Julius was merely ticking the appropriate ideological boxes in his speech, this type of language echoed through much medical discourse of the period, centreing around the need to construct health care services of a decidedly socialist nature (Osnovi Principi Nase Zdravstene Sluzbe, 1946; Policer, 1948; Nikolic, 1947; Julius, 1949; see also Antic, 2014; Antic, 2012).

Yet this type of language and tone was extraordinarily rare beyond the early 1950s, with practitioners generally avoiding any reference to ideological figureheads or the need to build up socialist psychiatry, preferring instead to justify their practices through a pantheon of theorists that would have been familiar to those in the West, ranging from Freud and Adler to Szasz and Laing. There were exceptions (e.g., Rajic, 1972; Opalic, 1977), but overt ideological penetration into psychiatric discourse was a true rarity, giving the impression that there was no longer any organised attempt to design a specifically socialist psychiatry. Although conferences might occasionally open with a speech that drew loosely upon the state's preferred political stances, these speeches were typically devoid of direct references to socialism, instead relying on vague allusions to concepts like "world peace"-something that might be seen as ideologically informed, but only tenuously. Concepts central to the Yugoslav variant of socialism-self-management, non-alignment, brotherhood and unity-were almost never directly addressed by practitioners from the early 1950s onwards.

Moreover, they do not seem to have been particularly preoccupied with any attempt to construct new types of specifically socialist citizens. In fact, it appears that practitioners were far more concerned with the protection and reproduction of one of the most traditional manifestations of citizenry-the patriarchal, extended family unit. Thus, while a multitude of researchers (e.g., Pecotic and Stanetti, 1962; Brajsa and Baldauf, 1968; Hudolin, 1971; Stanojevic et al., 1971; Petrovic, 1972; Miketic, 1975; Kapamadzija, 1976; Poleksic, 1981; Djukanovic, 1979) were directly concerned with the breakdown of family structures and how an epidemic of "broken homes" posed a threat to individuals' mental health, psychiatric theorists neglected to articulate any desire to craft new forms of socialist citizenry. Although a number of specialists in children's psychiatry were interested in encouraging more egalitarian family structures, they typically derived their justification for this movement from French practitioners like Serge Lebovici and Georges Heuyer, rather than any explicit intention to construct new forms of socialist families. Given the patronage system of Titoist Yugoslavia, in which the goodwill of party members could shape one's career prospects (a theme explored in greater detail below), it is difficult to understand why these practitioners would have neglected to mention socialism in their discussions, if this was indeed one of their stated goals.

What is fascinating, however, is that Yugoslav theorists did not simply retreat into the realm of the family as the locus of mental illness, despite the deep imprint of psychoanalytic and psychodynamic theories (Savelli, 2012; Antic, 2016). Rather, a powerful current that ran through Yugoslav mental health care implicated society more broadly as both the genesis and potential solution to mental health problems. These practitioners identified factors like poverty (Jorgic and Molnar, 1977; Petrovic, 1975), dislocation 
(Rogina, 1967; Skenderovic and Sakac, 1968; Vujosevic, 1972; Uglesic and Bokun, 1975; Kapamadzija et al., 1982), and alienation from modern life (Milcinski, 1974; Todorovic, 1984; Nikolic, 1985) as causal agents of mental illness. But where their counterparts elsewhere in the socialist world might have cited those conditions as the consequences of capitalism (Field, 1960; Korolenko and Kensin, 2002; Lee 1999), Yugoslav practitioners instead implicated the contemporaneous modernisation project itself-central to the overarching ideological transformation to Communism-as a source of mental distress. To be clear, Yugoslav practitioners did not openly object to the authorities' plans for industrialisation and urbanisation, but neither did they shy away from identifying those processes as central to epidemics of depression (Milakovic, 1961; Katicic, 1971), suicide (Poleksic, 1981; Markovic, 1975; Milcinski, 1975), and alcoholism (Despotovic et al., 1963; Poleksic, 1976). To improve the country's mental health, practitioners put forth a host of suggestions, including doing more to alleviate economic insecurity and to provide the conditions for a more meaningful existence.

Crucially, however, they did not explicitly ground their arguments in ideology. Rather, they linked their own work to research associated with the international social psychiatry movement, through figures like Joshua Bierer, as well as to better known UKbased practitioners, such as Aubrey Lewis and Maxwell Jones (Savelli, 2012). And although many within the social psychiatry movement might have identified with left-wing politics, few would have been understood as socialists in the context of Tito's Yugoslavia. The Yugoslav connection to these theorists was not born from a sense of social psychiatrists as comrades-in-arms, but in a rather more direct fashion: important Yugoslav theorists such as Dusan Petrovic, Vladimir Hudolin and Lev Milcinski each spent time studying in the UK at institutions like the Maudsley and the Marlborough Day Hospital, where social psychiatry took root. While in the UK, they adopted concepts like open-door treatment facilities and post-treatment patient clubs-practices meant to ensure that patients remained in society, rather than in institutions. Thus, while the ideas propagated by a host of the most important Yugoslav theorists were decidedly social by design, they were certainly not socialist, at least by Yugoslav standards.

\section{Socialist by default}

Yet the rarity of psychiatric practices that were socialist by design does not necessarily mean that socialism had no bearing on Yugoslav mental health care. Undoubtedly, Yugoslavia was transformed by the drive to construct a society built upon the principles of self-managing socialism; industrialisation and electrification drives fundamentally altered the countryside, largescale migrations fuelled mass urbanisation, and the authoritarian rule of the League of Communists of Yugoslavia served to create a context that was unmistakably socialist in its character. Psychiatry, without any doubt, was similarly impacted by these processes. As this section will argue, however, the relationship between ideology and psychiatry in Yugoslavia should be understood primarily as one whereby the political climate shaped the context for psychiatric developments, rather than acting as the theoretical basis or driving force of psychiatric knowledge itself. So while mental health care was indeed impacted by the overarching socialist system, this occurred by default, rather than by design.

The central role occupied by the League of Communists of Yugoslavia [LCY], the ruling party, provides a powerful example of how the political setting provided the framework for the profession's development. From the earliest postwar years, party membership and patronage structured the dynamics of everyday social and work life (Obradovic, 2013). LCY members were established in leading positions in virtually every professional sector throughout the Communist period, and psychiatry was hardly different in this respect. Party membership, although not necessarily a guarantor of success, was often a prerequisite for scaling professional heights. Consequently, party dynamics played an important role in shaping psychiatric developments, even if it did not mean any sort of imposition of the "party line" upon psychiatric theory or practice.

The example of Dezider Julius, one of Yugoslavia's leading practitioners in the immediate postwar era, demonstrates this point. An energetic psychiatric reformer at the head of the country's largest psychiatric facility (Vrapce hospital), Julius was a war hero (he and his wife, as well as both sons, had been Partisans) whose antifascist bona fides were beyond any doubt. Publicly, he hewed closely to the language and tone preferred by the Party. In a book published in 1948 about the atrocities carried out by German medical workers, for instance, he endorsed the pro-Soviet, anti-American stance that characterised official Party policy at the time (Julius, 1948). Shortly thereafter, in light of Tito's break with Stalin, Julius was equally vociferous in his criticism of Soviet leadership, accusing them of "monstrous attacks, slander, and lies" (Zapisnik, 1951, p 313). These sorts of demonstrations no doubt helped him cement his position as a leader in the field, aiming to reform Yugoslav psychiatry by serving as a professor of forensic psychiatry at Zagreb's medical faculty, co-founding the country's most important psychiatric journal (Neuropsihijatrija), and leading attempts to create Yugoslavia's first specialisation programme in psychiatry.

While it was clear that Julius was trusted by the party elite, he would soon run afoul of the local party apparatus; consequently, it would cost him his life. Although the exact details of the events remain obscure, the early 1950s witnessed an escalating series of conflicts between Julius and Party members working within Vrapce, led by the hospital tailor (Julius, 2003; Jukic 2008; Un Suicidio Ed Una Polemica, 1954). The tensions began when Julius, who as director had the final say over staffing, blocked the employment of several candidates put forward by the Party for positions he deemed unnecessary for hospital operations. In retaliation, Julius and the rest of the hospital administration were accused of corruption and theft. The discord intensified when Party members lost elections to the hospital's workers' council, a turn of events for which they blamed Julius. The situation in the hospital continued to deteriorate. Eventually, the Party staged a public meeting to discuss the matter. Local members laid out their case, but whenever Julius stood up to defend himself, he was whistled, booed, and shouted down. Rapidly, the event descended into an all-night verbal lynching as Julius' behaviour was called into disrepute, the details of which were printed by the local press. A short while after the meeting, Julius walked into his office at the hospital, wrote a few letters, and shot himself.

More than 150 physicians, aghast at seeing Julius bullied into suicide by the mob justice of the local Party, published an open letter condemning such an abuse of power (Julius, 2003). Eventually Vladimir Bakaric, Croatia's then Prime Minister, responded with his own article about the Julius case, framing what had happened at the hospital as a struggle between the old and the new. In his words, Julius had been waging a battle for the old privileges of the hospital staff against the new system of socialism. Bakaric described Julius as "an honourable fighter and a revolutionary who unfortunately died from a stray bullet" (Julius, 2003, p 323). His eventual obituary in Neuropsihijatrija (the journal he co-founded) praised him both as a psychiatrist and a war hero, although it neglected to mention the specific details of his death, other than describing it as "tragic" (Lopasic, 1953). 
Many of the reforms that Julius had proposed, including splitting neurology and psychiatry into two separate disciplines rather than the conjoined field of neuro-psychiatry, which intuitively implied a biological basis for mental illness, died along with him. Yet the Julius tragedy was not the result of some sort of theoretical disagreement with the Party over whether mental illness was organic in nature; rather, it stemmed from his refusal to allow the local cell to dictate staffing policies at Vrapce. These prosaic concerns thus did impact the development of Yugoslav psychiatry, but it was by default, rather than any active attempt to craft a specifically socialist vision of psychiatry. Clearly, these events were products of a context in which the Party enjoyed substantial power, but they should not be understood as a reflection of attempts to design a new form of ideologically pure psychiatry.

We should be cautious about understanding the Party as a monolith. Holding party membership did not necessarily translate to slavish devotion to the League of Communists, its slogans, or ideals. On the contrary, one distinctly gets the impression that many psychiatrists were in fact using the party to their own advantage, either for personal gain or to advance their research interests and pet projects. Yet such a strategy would not necessarily preclude them from participating in the broader struggle to establish Communism either, and there is little use in thinking about the issue in a strictly binary fashion; individuals could both loosely adhere to ideological goals while also using ties to the elite for their own professional advantage.

The example of Slavka Moric-Petrovic proves illustrative in this respect. Moric-Petrovic was an "old Communist," having joined the Party in 1940, before hostilities broke out in Yugoslavia (and thus before the formation of Tito's antifascist resistance). Her wartime record as a daring courier and Party organiser saw her quickly rise up the ranks of the Belgrade leadership, earning her numerous distinctions in the postwar period. Moric-Petrovic was subsequently able to translate her political capital into support for the creation of the Institute of Mental Health, which opened in Belgrade in 1963. ${ }^{4}$ A direct challenge to psychiatric convention, which at that time still favoured large custodial hospitals, the Institute sought to apply the principles of the emerging international social psychiatry movement to Yugoslav society, with the mandate of helping "the mental patient to solve his problems away from the artificial divergence of the hospital" since the patient "should be a complementary part of the social and cultural environment" (Petrovic, 1972, p 3) The Institute's community orientation, open-door policy, and focus on rehabilitation shattered many pre-conceived notions of psychiatric care, being met with suspicion in those quarters that still believed in confinement as the primary response to mental illness. The first institute of its kind in the Balkans, it would go on to become one of the leading centres of psychiatric research in Yugoslavia, helping to build the country's considerable expertise in social psychiatry through collaborations with practitioners from the United States, Britain, France, and elsewhere.

The stories of both Julius and Moric-Petrovic undoubtedly belong to the world of socialism, but they might better be characterised as "socialist by default" rather than "socialist by design." They are emblematic of the way in which personal politics often trumped macro issues like ideology-control of hospitals could be won and lost by currying favour with the local Party executive rather than crafting psychiatric practices that were ideologically pure. After all, Julius was one of the very few practitioners to attempt to articulate some vision of psychiatry that was decidedly socialist in tone and outlook (Julius 1949; Zapisnik, 1951). Moric-Petrovic, meanwhile, used her Institute of Mental Health to employ several individuals who were thought to be somewhat politically suspect, such as Vojin Matic (Klajn,
1989, p 82). These cases did not involve the party making attempts to craft a specifically socialist psychiatry (which might be used to forge new types of socialist citizens or "treat" ideological non-conformers), but rather they reflected how the power of the Party could nonetheless profoundly shape psychiatric developments.

These examples are illustrative, but they are by no means exhaustive. Yugoslav psychiatry was littered with many other developments that were socialist by default rather than by design. Whether proposing that self-managing workers' councils be pressed to ban liquor in workplace cafeterias to combat alcoholism (Nikolic, 1987) or giving substantial attention to the way that Yugoslav citizens might make use of the country's generous system of disability claims (e.g., Spicer and Hudolin, 1963; Persic, 1964; Katicic, 1971), practitioners were continually practicing a psychiatry that was very much shaped by socialism, without being theoretically beholden to it. Thus, here we can see an important distinction: these clinicians were not really practicing socialist psychiatry, rather, they were simply practicing psychiatry with socialism as the backdrop.

\section{Conclusion}

Of course, separating a practitioner's actions, behaviours, and practices from the overarching ideological environment is not something that can be done with precision. While it is worthwhile to differentiate whether psychiatry was socialist by design or by default, it is not always possible to disentangle one from the other. Naturally, professional knowledge is simultaneously shaped by a practitioner's own beliefs and social ambitions, as well as the legal, material, and political constraints of reality-themselves often consequences of the overarching ideological system. From this perspective, the issue of design/default should not be understood as a hard binary, but rather as interrelated, yet separate, phenomena.

With that provision in mind, however, there is still value in trying to consider the distinction between the two. For one, psychiatry simply cannot be analysed or understood independently from the social environment. With its diagnostics so often relying on concepts such as "excessive," "inappropriate," and "bizarre," the profession is inextricably connected to the social ideologies that govern expectations about proper and healthy behaviour. By studying whether psychiatric theory was socialist by design, therefore, we learn something about the relationship between medical science and society within the Communist context. In doing so, we consequently discover new ways to conceptualise the socialist experiments of the last century, gaining a better idea of how ideological and political precepts might have shaped expectations about "appropriate" or "normal" thoughts, feelings, and behaviour.

By considering how professional practices might have been socialist by default, meanwhile, we open up the possibility of viewing psychiatry within Communist contexts as part of the broader evolution of the mental health care in the twentieth century, rather than as some kind of isolated and backward exotica. In doing so, this perspective contributes to a broader decentreing of psychiatric history, moving away from the sense that Western Europe and North America were the sources of real knowledge about mental health and illness, while the rest of the world lagged behind. Such a change in thinking would be most welcome given that, in the twenty-first century, we are still no closer to knowing the ontological truth about many of psychiatry's key precepts. Finally, the concept of "socialist by default" also allows us to see how diagnostic and therapeutic practices could be impacted by ideology without necessarily being beholden to it, a notion worth considering in light of the fact that all 
forms of psychiatry occur within an ideological context of one sort or another.

Received: 14 December 2017 Accepted: 26 March 2018

Published online: 17 April 2018

\section{Notes}

1 At a recent workshop entitled the "Boundaries of Socialist Medicine," organiser Dora Vargha encouraged participants to think widely on precisely what might entail "socialist medicine." Earlier, Greg Eghigian (2002) raised the question of whether "socialist psychiatry" ever truly existed. In later work (2005), Eghigian drew attention to how the psy-disciplines blossomed in both socialist totalitarian and liberal contexts as a way to identify and ameliorate abnormality and the threat it posed to society, regardless of ideological underpinnings.

2 Scholarly work, by contrast, has of course drawn attention to the way that Western political contexts have shaped the development of psychiatry in those places. As examples, see Rose (2009), Metzl (2010), and Staub (2011).

3 This third point is heavily indebted to one of the anonymous reviewers.

4 Psychiatrists questioned about this matter revealed their certainty that Belgrade's Institute of Mental Health would not have been built had it not been for MoricPetrovic's direct intervention. Moric-Petrovic utilised her respected position within the party to extract funding, materials, and resources to improve the mental health services in Belgrade and beyond. Interviews and correspondence with Kecmanovic (2008), Bojanin (2008), Petrovic (2007), and Eric (2007)

\section{References}

Abuse of Psychiatry for Political Repression in the Soviet Union (1973) United States Senate. Committee on the Judiciary. Arno Press, New York

Allen MG (1973) Psychiatry in the United States and the USSR: A comparison. Am J Psychiatry 130(12):1333-1337

Amnesty International (1975) Prisoners of conscience in the USSR: Their treatment and conditions. Amnesty International Publications, London

Antic A (2012) Psychiatry at war: Psychiatric culture and political ideology in Yugoslavia under the Nazi Occupation. Doctoral dissertation, Columbia University

Antic A (2014) Heroes and hysterics: 'Partisan Hysteria' and communist statebuilding in Yugoslavia after 1945. Soc Hist Med 27(2):349-371

Antic A (2016) The pedagogy of workers' self-management: terror, therapy, and Reform Communism in Yugoslavia after the Tito-Stalin split. J Soc Hist 50 (1):179-203

Aronson J, Field MG (1964) Mental health programming in the Soviet Union. Am J Orthopsychiatry 34(5):913-924

Beer D (2007) Blueprints for change: the human sciences and the coercive transformation of deviants in Russia, 1890-1930. Osiris 22(1):26-47

Bloch S (1978) Psychiatry as ideology in the USSR. J Med Ethics 4(3):126-131

Bloch S, Reddaway P (1977) Russia's Political Hospitals: The Abuse of Psychiatry in the Soviet Union. Gollancz: London.

Bojanin S (2008) 26 February 2008 (Interview in Belgrade)

Brajsa P, Baldauf J (1968) Obitelj-Psihodinamski i sociodinamski faktori u sastajanju i razvoja psihickih poremecaja. III Kongres Neurologa i Psihijatara Jugoslavije. Split, Yugoslavia

Brown A (2009) The rise and fall of communism. Random House, London

Brown JV (1994) Heroes and non-heroes: Recurring themes in the historiography of Russian-Soviet psychiatry. In: Micale MS, Porter R (eds) Discovering the history of psychiatry. Oxford University Press, Oxford, pp 297-307

Chehirian J (2017) Excavating the psyche: A social history of Soviet psychiatry in Bulgaria. Culture, medicine, and psychiatry advance online publication 17 November, https://doi.org/10.1007/s11013-017-9559-2

Crampton RJ (2005) Eastern Europe in the twentieth century-and after. Routledge: London

Despotovic A, Stojilkovic S, Petrovic F (1963) Analiza socijalne strukture lecenih alkoholicara. Simpozij o alkoholizmu - pod pokriviteljstvom dra Tode Curuvije. Anali Bolnice Dr. M. Stojanovic 5(1): 287-300

Djukanovic B (1979) Alkoholizam i Porodica. Republika Zajednica Nauke SR Srbije: Belgrade

Dobos C (2015) Psychiatry and ideology: The emergence of 'Asthenic Neurosis' in communist Romania. In: Savelli M, Marks S (eds) Psychiatry in Communist Europe. Palgrave, London, pp 93-116

Dufaud G, Rzesnitzek L (2016) Soviet psychiatry through the prism of circulation: the case of outpatient psychiatry in the interwar period. Krit: Explor Russ Eurasia Hist 17(4):781-803

Eghigian G (2002) Was there a Communist psychiatry? Politics and East German psychiatric care, 1945-1989. Harv Rev Psychiatry 10(6):364-368
Eghigian G (2004) The psychologization of the socialist self: East German forensic psychology and its deviants, 1945-1975. Ger Hist 22(2):181-205

Eghigian G (2005) Care and control in a communist state: The place of politics in East German psychiatry. In: Gijswijt-Hofstra M, Oosterhius H, Vijselaar J, Freeman $\mathrm{H}$ (eds) Psychiatry and mental health care in the twentieth century: comparisons and approaches. Amsterdam University Press, Amsterdam, pp 183-199

Eric LJ (2007) 10 September 2007 (Interview in Belgrade).

Etkind A (1997) Eros of the impossible: The history of psychoanalysis in Russia. Westview Press, Boulder

Fainberg V (1975) The abuse of psychiatry in the USSR: My five years in mental hospitals. Index Censorsh 4(2):67-71

Field MG (1960) Approaches to mental illness in Soviet society: some comparisons and conjectures. Soc Probl 7(4):277-297

Field MG, Aronson J (1965) Soviet community mental health services and work therapy: A report of two visits. Community Ment Health J 1(1):81-90

Fireside H (1979) Soviet Psychoprisons. George J. McLeod Limited, Toronto

Gao Z (2015) Pavlovianism in China: Politics and differentiation across scientific disciplines in the Maoist era. Hist Sci 53(1):57-85

Hess G (1971) Impressions of mental health service delivery systems in Finland Poland, Soviet Russia and Czechoslovakia. Int J Nurs Stud 8(4):223-235

Hudolin V (1971) Rehabilitacija alkoholicara i narkomana. III Kongresa Lekara Jugoslavije. Bled, Yugoslavia

Joravsky D (1989) Russian psychology: A critical history. Basil Blackwell, Oxford

Jorgic S, Molnar I (1977) Utjecaj drustveno ekonomskih uvjeta na psihopatolosku sliku depresivnih stanja. Soc Psihijatr 5(3):329-332

Julius D (1948) Lijecnici - ratni zlocinci. Medicinska Knjiga, Belgrade

Julius D (1949) Pitanja socijalne psihopatologije. Nar Zdr 6:5

Julius S (2003) Neither Red nor Dead: Coming of Age in Former Yugoslavia during and after World War II. Medvista, Ann Arbor

Jukic V (2008) February 2008 (Interview in Zagreb)

Kapamadzija B (1976) Suicid Mladih. Psihijatr Danas 8(3-4):361-372

Kapamadzija B, Biro M, Sovljanski M (1982) Socio-psihijatrijska i patomorfoloska analiza 100 izvrsenih samoubistava. Soc Psihijatr 10(1):35-56

Karge H (2017) Afflicted heroes: The rise and fall of Yugoslav war neurosis after the Second World War. In: Bernasconi S, Karge H, Kind-Kovacs F (eds) From the midwife's bag to the patient's file: Public health in Eastern Europe. CEU Press, Budapest, pp 217-235

Katicic N (1971) Radna sposobnost i lijecenje reaktivnih depresija. In: Persic N (ed) Socijalna Psihijatrija. Pliva, Zagreb, pp 617-621

Kecmanovic D (2008) 11 July 2008 (Correspondence with the author)

Klajn P (1989) Razvoj Psihoanalize U Srbiji. Pedagoska Akademija, Subotica

Kline NS (1960) The organization of psychiatric care and psychiatric research in the Union of Soviet Socialist Republics. Ann N Y Acad Sci 84(1):149-223

Kline NS (1963) Psychiatry in Yugoslavia. Psychiatr Q 37(2):245-252

Korolenko CP, Kensin DV (2002) Reflections on the past and present state of Russian psychiatry. Anthropol \& Med 9(1):51-64

Lambe JL (2017) Revolutionizing Cuban psychiatry: The Freud wars, 1955-1970. Bull Hist Med 91(1):62-93

Lee S (1999) Diagnosis postponed: Shenjing Shuairuo and the transformation of psychiatry in post-Mao China. Cult Med Psychiatry 23(3):349-380

Leuenberger C (2001) Socialist psychotherapy and its dissidents. J Hist Behav Sci $37(3): 261-273$

Leuenberger C (2007) Cultures of categories: Psychological diagnoses as institutional and political projects before and after the transition from state socialism in 1989 in East Germany. Osiris 22(1):180-204

Lopasic R (1953) Prof. Dr. Dezider Julius 1895-1953. Neuropsihijatrija 1 (4):266-267

Markovic A (1975) Proucavanje suicidalnog ponasanja. Soc Psihijatr 3(1):19-32

Marks S, Savelli M (2015) Communist Europe and transnational psychiatry. In: Savelli M, Marks S (eds) Psychiatry in Communist Europe. Palgrave, London, pp 1-26

Marks S (2015) From experimental psychosis to resolving traumatic pasts: psychedelic research in communist Czechoslovakia, 1954-1974. Cah du Monde Russe 56(1):53-76

Medvedev ZA, Medvedev RA (1971) A question of madness. MacMillan Ltd, London

Metzl JM (2010) The protest psychosis: How Schizophrenia became a black disease. Beacon Press, New York

Miketic B (1975) Uticaj porodice na nastajanja suicidalnosti u dece. II Jugoslovenski Simpozijum o Prevenciji Suicida. Bled, Yugoslavia

Milakovic I (1961) Dinamicki aspekt neuroza u industriji. Neuropsihijatrija 9 (2-3):127-134

Milcinski L (1975) Reflections on specific features of suicide in Yugoslavia. Soc Psihijatr 3(4):289-298

Milcinski L (1974) Tretiranje narkomanija-represija ili terapija. Soc Psihijatr 2 (1):61-68

Miller MA (1998) Freud and the Bolsheviks: Psychoanalysis in imperial Russia and the Soviet Union. Yale University Press, New Haven 
Moss CS (1967) Visitation to mental health programs in Eastern Europe. Am Psychol 22(6):452-456

Nikolic N (1947) Planiranje zdrastvene sluzbe. Med Glas 1(6):107-108

Nikolic D (1985) Kretanje broja alkoholicara u SFR Jugoslaviji i preventivna zastita. Soc Psihijatr 13(4):281-294

Nikolic D (1987) Primary health care and alcoholism in Yugoslavia. Soc Psihijatr 15(3):273-280

Obradovic M (2013) From revolutionary to clientelistic party: The communist party of Yugoslavia, 1945-1952. East Eur Polit Soc 27(3):376-399

Opalic P (1977) O dijalektickom shvatanju ljudske prirode i socioterapiji. Psihijatr Danas 2(4):437-447

Osnovi Principi Nase Zdravstene Sluzbe (1946) Med Glas 1(3):46

Pecotic M, Stanetti F (1962) Mentalno-higijenski aspekti nagle industrijalizacije u Jugoslaviii. Neuropsihijatrija 10(1-2):40-44

Persic N (1964) Ocjenjivanje radne sposobnosti psihijatriskih bolesnika. Lijec Vjesn 86(11):1309-1409

Petrovic D (1975) Znacaj socijalnih faktora u depresija u starosti. Soc Psihijatr 3 (4):307-321

Petrovic D (1972) Institute for Mental Health Belgrade. Institut za Mentalno Zdravlje, Belgrade

Petrovic D (2007) 9 August 2007 (Interview in Belgrade)

Pipes R (2003) Communism: A history. Random House, New York

Poleksic J (1981) Domicijalni determinantne presuicidalnog sindroma u senescenciji. Engrami 2(3):55-62

Poleksic J (1976) Ucestalost, uzroci i socijalno-medicinske posledice alkoholizma u rudara Kolubarskog basena. Naucna Knjiga, Belgrade

Policer S (1948) Lekari i zdrastveno prosvecivanje. Med Glas 2(4):71

Priestland D (2016) The red flag: A history of communism. Grove Atlantic, Inc, New York

Rajic S (1972) Covjek i autoritet. Internacionalni Simpozijum o Rehabilitaciji u Psihijatriji. Belgrade, Yugoslavia

Reddaway P (1978) KGB psychiatry-out but not down. Quadrant 22(10):32-35

Rogina V (1967) Suvremene tendencije u zbrinjavanju psihijatriskih bolesnika. Civilno-Pravni Status i Problemi Zastite Psihijatrijskih Bolesnika, II Savjetovanje o Forenzickoj Psihijatari. Zagreb, Yugoslavia

Rose N (2009) The Politics of Life Itself: Biomedicine, Power, and Subjectivity in the Twenty-First Century. Princeton University Press, Princeton

Salvendy JT (1975) Psychiatry in the Soviet Union today. Can Psychiatr Assoc J 20 (3):229-236

Savelli M (2012) Diseased, depraved or just drunk? The psychiatric panic over alcoholism in communist Yugoslavia. Soc Hist Med 25(2):462-480

Savelli M (2015) Blame George Harrison: Drug use and psychiatry in communist Yugoslavia. In: Savelli M, Marks S (eds) Psychiatry in Communist Europe. Palgrave, London, pp 180-195

Segal BM (1977) Soviet approaches to involuntary hospitalisation. Int J Social Psychiatry 23(2):94-102

Service R (2010) Comrades! A history of world communism. Harvard University Press, Cambridge

Skenderovic F, Sakac DJ (1968) Pracenje nekih faktora u epidimiologiji samoubistava u Vojvodini. III Kongres Neurologa i Psihijatara Jugoslavije. Split, Yugoslavia

Sirotkina I, Kokorina M (2015) The dialectics of labour in a psychiatric ward: Work therapy in the Kaschenko hospital. In: Savelli M, Marks S (eds) Psychiatry in Communist Europe.. Palgrave, London, pp 27-49

Spicer F, Hudolin V (1964) Alkoholizam i radna sposobnost. Simpozij o Alkoholizmu. Anali Bolnice Dr. M. Stojanovic 3(1): 81-88

Staub ME (2011) Madness is Civilization: When the Diagnosis Was Social, 19481980. University of Chicago Press, Chicago
Stanojevic DJ, Pavlovic J, Jorgacevic D (1971) Znacaj sredine u motivaciji pokusaja suicida. In: Persic N(ed.) Socijalna Psihijatrija. Pliva, Zagreb, pp 143-148

Todorovic M (1984) Depresija-bolest danasnjice. Psihijatr Danas 16(3-4):323-333

Uglesic B, Bokun P (1975) Psihijatrijski aspekt ekonomske emigracije. Soc Psihijatr 3(3):205-213

Un Suicidio Ed Una Polemica (1954) L'Arena di Pola 902, 27 Jan: 1. Gorizia, Italy

Vujosevic K (1972) Marihuana u danasnjem svetu. Zbornik Radova Prvog Jugoslavenskog Simpozijuma o Prevenciji i Lecenju Narkomanija. Nis: Institut Jugoslovenske i Inostrane Dokumentacije Zastite na Radu

Windholz G (1997) The 1950 joint scientific session: Pavlovians as the accusers and the accused. J Hist Behav Sci 33(1):61-81

Windholz G (1999) Soviet psychiatrists under Stalinist duress: the design for a 'New Soviet Psychiatry' and its demise. Hist Psychiatry 10(39):329-347

Zajicek B (2009) Scientific psychiatry in Stalin's Soviet Union: The politics of modern medicine and the struggle to define 'Pavlovian' psychiatry, 1939-1953. Dissertation, The University of Chicago

Zajicek B (2014) Soviet madness: Nervousness, mild schizophrenia, and the professional jurisdiction of psychiatry in the USSR, 1918-1936. Ab Imp 2014 (4):167-194

Zapisnik Naunog Sastanka Neurologa I, Psihijatara FNRJ (1951) Zbornik Drugog Naucnog Sastanka Neuro-Psihijatara u Opatiji 1949. Medicinska Knjiga, Belgrade

Ziferstein I (1966) The Soviet psychiatrist: His relationship to his patients and to his society. Am J Psychiatry 123(4):440-446

\section{Data availability}

Data sharing is not applicable to this article as no data sets were generated or analysed during the current study.

\section{Additional information}

Competing interests: The author declares no competing interests.

Reprints and permission information is available online at http://www.nature.com/ reprints

Publisher's note: Springer Nature remains neutral with regard to jurisdictional claims in published maps and institutional affiliations.

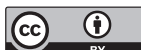

Open Access This article is licensed under a Creative Commons Attribution 4.0 International License, which permits use, sharing, adaptation, distribution and reproduction in any medium or format, as long as you give appropriate credit to the original author(s) and the source, provide a link to the Creative Commons license, and indicate if changes were made. The images or other third party material in this article are included in the article's Creative Commons license, unles indicated otherwise in a credit line to the material. If material is not included in the article's Creative Commons license and your intended use is not permitted by statutory regulation or exceeds the permitted use, you will need to obtain permission directly from the copyright holder. To view a copy of this license, visit http://creativecommons.org/ licenses/by/4.0/

(C) The Author(s) 2018 